\title{
Kontrol Diri di Media Sosial Perspektif Pemikiran Hermeneutika Hadis Khaled Abou El-Fadl
}

\author{
Muhsin \\ Universitas Islam Negeri Alauddin Makasar \\ Email: muhsinmahfudz@uin-alaluddin.ac.id \\ Muhammad Arif \\ Universitas Islam Negeri Alauddin Makasar \\ Email: ariefbinyunus@uin-alaluddin.ac.id
}

\begin{abstract}
The main discussion in this paper is how the perspective of the hadith of the Prophet. regarding oral and hand care? Then described in the sub-problems as follows: 1 . What is the quality of the hadith about oral and hand keeping? 2. What is the content of the hadith about oral and hand keeping? 3 . What are the forms of the hadith application about keeping oral and hand on social media?. Resolving this problem, the author uses a hermeneutical approach in understanding the hadith. Purpose of this study is to find out the quality of the hadith, the content of the hadith and the form of the application of hadith about oral and hand keeping in the world of social media. The estimation of the findings of this study is that this oral guardianship is not only placed in a legal and normative context. Rather it involves the culture and norms of life. In the context of eastern society which refers to the values and order of the east, it is assumed that human beings are part of another human being that is inseparable so as to form a prosperous society protected from deception due to not keeping oral.
\end{abstract}

Kata kunci: Social Media, Hadith, Hermeneutic

Abstrak: Artikel ini membahas tentang bagaimana perspektif hadis Nabi saw. mengenai menjaga lisan dan tangan? Lalu dijabarkan dalam sub-sub masalah sebagai berikut: 1. Bagaimana kualitas hadis tentang menjaga lisan dan tangan? 2. Bagaimana kandungan hadis tentang menjaga lisan dan tangan? 3. Bagaimana bentuk pengaplikasian hadis tentang menjaga lisan dan tangan dalam media sosial?. Menyelesaikan permasalahan ini, penulis menggunakan pendekatan hermeneutika dalam memahami hadis. Tujuan penelitian ini untuk mengetahui kualitas hadis, kandungan hadis dan bentuk pengaplikasian hadis tentang menjaga lisan dan tangan di dunia medsos. Adapun perkiraan hasil temuan dari penelitian ini adalah persolan menjaga lisan ini tidak hanya didudukkan dalam konteks hukum dan normative. Melainkan melibatkan budaya dan normanorma kehidupan. Dalam konteks masyarakat timur yang mengacu pada nilai-nilai dan tatanan ketimuran menggangap bahwa manusia adalah bagian dari manusia yang lain yang tidak terpisahkan sehingga membentuk sebuah masyarakat yang sejahtera terhindar dari pembodohan akibat tidak menjaga lisan.

Keyword: Sosial Media, Hadis, Hermeneutika 


\section{PENDAHULUAN}

Pemahaman seseorang terhadap hadis tidaklah sama dan tidak semua hadis juga dapat dipahami hanya melalui teks formalnya saja. Ada yang dapat dipahami ketika melihat teks formalnya dan adapula yang dipahami ketika melihat dari segi substansi kontekstualnya. Maka dibutuhkan pengkajian lebih lanjut terhadap hadis-hadis tersebut agar umat Islam tidak salah dalam pengaplikasian hadis-hadis Nabi Muhammad saw.

Muslim yang terbaik adalah mampu memahami hadis Nabi Muhammad saw., secara teoretis maupun praktis baik yang berkaitan dengan masalah ibadah, aqidah, maupun akhlak.

Di era modern ini, banyak umat Islam yang telah jauh menyimpang dari dan hadis, hanya mementingkan kepentingan duniawi dan meninggalkan kepentingan akhirat. Hal tersebut mengakibatkan berkembangnya isu-isu yang meresahkan masyarakat. Di antaranya ialah dua isu yang berkembang dan mempengaruhi khalayak yaitu media elektronik khususnya dari aspek info-info entertainment-nya dan tindakan tidak menjaga lisannya di media sosial sehingga dampaknya mengarah kepada bentuk tindak kekerasan didunia nyata. Kedua masalah tersebut merusak eksistensi seorang muslim dan mengingkari hadis Nabi Muhammad saw. yang berbunyi sebagai berikut:

حَدَّنَنَا زَيْنُ بْنُ الْحُبَابِ ، أَخْبَرَنِ مُوسَى بْنُ

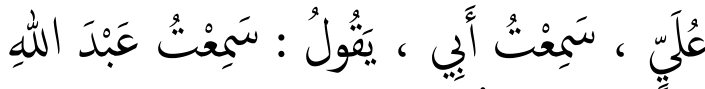

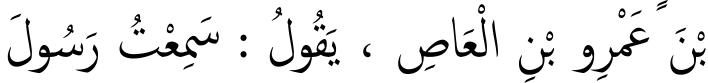

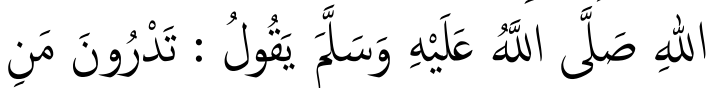

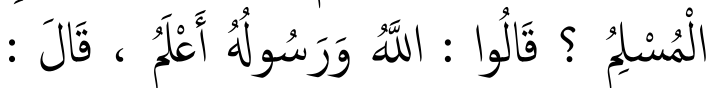

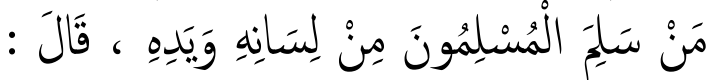

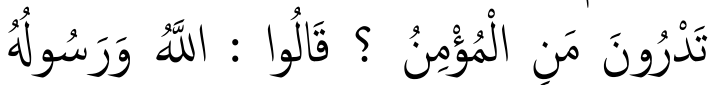

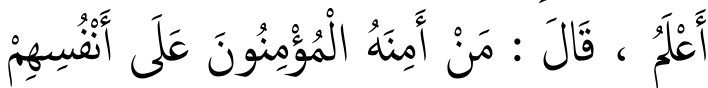

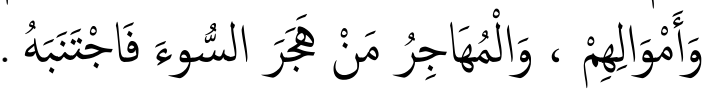

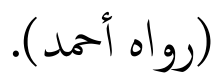

Artinya:

Telah menceritakan kepada kami Zaid Ibnul Hubbab telah mengkhabarkan kepadaku Musa bin Aliy aku mendengar bapakku berkata; Aku mendengar Abdullah bin 'Amru bin Al 'Ash berkata; aku mendengar Rasulullah 
Shallallahu 'alaihi wa Salam bersabda: "Tahukah kalian siapa itu muslim?" Mereka menjawab: "Allah dan RasulNya lebih tahu." Beliau bersabda: "Seorang muslim adalah jika kaum muslimin merasa aman dari bahaya lisan dan tangannya." Beliau bersabda: "Tahukah kalian siapa itu mukmin?" Mereka menjawab: "Allah dan RasulNya lebih tahu." Beliau bersabda: "Seorang mukmin adalah jika orang-orang mukmin merasa aman darinya terhadap jiwa dan harta mereka. Dan seorang Muhajir adalah orang yang menjauhi keburukkan. ${ }^{1}$

Dari aspek kualitasnya, hadis tersebut sahih dapat dipertanggung jawabkan kesahihannya karena melihat para rawi dan jalur sanad pada hadis tersebut. Selain itu hadis tersebut diriwayatkan oleh alBukhārī dan Muslim dalam kitab shahih-nya, Abū Dāwud dalam Sunan-nya, al-Turmużī dalam Sunannya, al-Nasā'ī dalam Sunan-nya, alDārimī dalam Sunan-nya, al-Humaidī dalam Musnad-nya, al-Syaibānī dalam Sunnah-nya, al-Bazzār dalam

1 Abu 'Abdullah Ahmad Ibn Hanbal, Musnad al-Imam Ahmad bin Hanbal, Jilid I (Cet. I; t.t.: Mu'assasah al-Risalah, 2000), 521.
Musnad-nya, Ibn Hibbān dalam shahih-nya, dan al-Ṭabrānī dalam berbagai $M u^{\prime} j a m$-nya.

Aspek pemahaman hadis ini, menjaga lisan dan tangan merupakan simpel dan mudah dilanturkan. Akan tetapi, mengamalkannya tidak semudah membalikkan telapak tangan karena ketika manusia tidak mempergunakannya sesuai dengan syariat maka akan terjadi berbagai kerusakan di muka bumi ini. Namun, ketika orang muslim lainnya selamat dari bahaya lisan dan tangannya dan orang muslim merasa aman darinya terhadap jiwa dan hartanya maka hal tersebut menjadi tanda kesempurnaan iman seorang muslim..$^{2}$

Lisan merupakan salah satu panca indera yang dianugerahkan Allah swt. kepada hamba-Nya. Sekalipun bentuknya kecil tapi fungsinya amatlah besar. Tidak akan jelas keimanan dan kekafiran kecuali dengan kesaksian yang dituturkan

2 Jamal al-Din Abu al-Faraji 'Abd alRahman Ibn 'Ali Ibn Muhammad al-Jawazi, Kasfy al-Musykil min Hadis al-Sahihain, Jilid III (Riyadh: Dar al-Watan, t.th.), 77. 
lewat lisan. Lisan juga mempunyai jangkauan yang luas, baik dalam kebaikan atau dalam kejahatan. Hal ini merupakan keistimewaan yang hanya dimiliki oleh lisan, tidak ada anggota tubuh lain yang memiliki keistimewaan seperti ini. Mata hanya dapat melihat yang berwarna dan bergambar, telinga hanya dapat mendengar yang bersuara, tangan hanya dapat menggapai yang berjasad begitu juga dengan anggota tubuh yang lainnya ${ }^{3}$. Banyak di antara umat manusia yang menganggap remeh dan terseret ke arah penyakit lisan. Banyak hubungan persaudaraan antara sesama muslim maupun kafir yang rusak diakibatkan karena tidak menjaga lisan. Di antaranya ialah gibah, fitnah dan namimah.

Nabi Muhammad saw. menasehati umatnya untuk menjaga lisan dengan baik, sebagaimana sabda beliau:

3 Raja' Thaha Muhammad Ahmad, Min Kunuz al-Sunnah, Terj. Fathurrahman Hamid, Akhlaqi wa al-Suluki wa al-Suluti Hifzhul Lisan dan Penuntun Akhlak Keluarga, Cet. I (Semarang: Pustaka Adnan, 2005), 5.

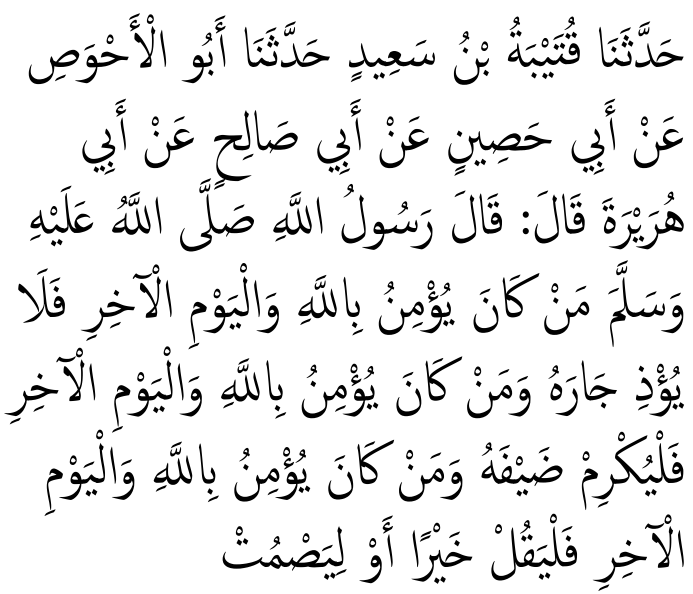

Artinya:

“Telah menceritakan kepada kami Qutaibah bin Sa'id telah menceritakan kepada kami Abu Al Ahwash dari Abu Hashin dari Abu Shalih dari Abu Hurairah dia berkata; Rasulullah shallallahu 'alaihi wasallam bersabda: "Barangsiapa berimana kepada Allah dan hari Akhir, janganlah ia mengganggu tetangganya, barangsiapa beriman kepada Allah dan hari Akhir hendaknya ia memuliakan tamunya dan barangsiapa beriman kepada Allah dan hari Akhir hendaknya ia berkata baik atau diam. (H.R Bukhari). ${ }^{4}$ Anggota tubuh yang lain pun tidak luput dari bahaya seperti halnya dengan tangan. Tangan juga

4 Muhammad Ibn Isma'il Abu Abdillah al-Bukhari al-Ju'fi, al-Jami' al-Sahih, Jilid VIII (Beirut: Dar Ibn Kasir, 1987 ), 11. Lihat juga Muslim Ibn al-Hajjaj Abu alHusain al-Qusyairi al-Naisaburi, Sahih Muslim, jilid 1 (Beirut: Dar Ihya' al-Tarat al'Arabi, t. th.), 11. 
bisa mendatangkan bahaya bagi muslim lainnya karena tangan merupakan lisan kedua manusia. Tangan merupakan salah satu anggota tubuh yang sering menimbulkan bahaya baik bagi diri sendiri maupun orang lain, dari perbuatan, sikap maupun keputusankeputusannya.

Disebutkan tangan dalam hadis tersebut bukan hanya terbatas pengertian tangan secara fisik akan tetapi dapat diartikan kekuasaan. Sebagaimana arti kata "yad" dalam Maqayis al-Lugah yaitu lafal al-yad terdiri dari dua huruf dasar yaitu al$y a$ ' dan al-dāl, bermakna "pangkal tangan", dapat digunakan bagi manusia maupun selainnya. Terkadang juga diartikan dengan alminnah (pemberian) ${ }^{5}$.

Hemat penulis, al-yad diartikan dengan pemberian karena sebuah hadiah atau pemberian dari tangan pemberi ke tangan orang yang diberi. Tangan akan membahayakan pemiliknya maupun

5 Abu al-Husain Ahmad Ibn Faris, Mu'jam Maqayis al-Lugah, Jilid VI, (Beirut: Dar al-Fikr al-'Ilmiyya, 2011), 151. orang-orang sekitar ketika tidak digunakan sesuai dengan syariat. Apalagi jika tidak didasari dengan keimanan yang kuat. Apabila setan telah menguasai hatinya maka ia akan bertindak sesukanya.

Anjuran Nabi dalam menjaga lisan dan tangan jikalau di sandingkan dengan realitas media sosial, maka akan menimbulkan berbagai macam pendapat Ulama maupun pemikir hadis. Seiring dengan perkembangan zaman dan untuk membuktikan kandungan sebuah hadis diperlukan adanya pemaknaan ulang atau reinterpretasi terhadap sebuah hadis. Karena sejatinya kegidupan manusia diliputi dari berbagai macam situasi dan kondisi. Sehingga perdebatan atas pendukung dan yang menolak menjaga lisan dan tangan secara filosofis dan normative merupakan pertarungan ideologis. Nilai Islam yang mengharuskan menjaga lisan dan tangan tidak dapat dipandang sebagai sebuah ketentuan larangan semata tanpa melihat argumentasi filosofis atas larang tersebut. 
Dewasa ini, kaum intelektualis telah menyuguhkan sebuah pendekatan hermeneutika dalam memahami sebuah teks. Sejalan dengan hal tersebut, penulis memilih hermeneutika Khaled Abou Fadl, yang dikenal dengan istilah hermeneutika negosiatif.

Menurut hemat penulis, pisau analisis yang ditawarkan oleh Khaled Abou Fadl dianggap mampu memetakan persoalan menjaga lisan dan tangan di media sosial tersebut dengan metode triadik hermeneutika negosiatifnya, di mana pemahaman sebuah teks itu melibatkan 3 unsur yang menjalin rangkaian dialektika antara teks, pembaca dan realitas (berbagai disiplin keilmuwan, tradisi, peradaban dan sebagainya). Meskipun yang menjadi titik tekan dalam teori triadic ini adalah pembaca, karena pembacalah yang terud menerus mengalami dinamika perubahan, namun perubahan tersebut sejatinya dilandasi oleh situasi dan kondisi yang mengitarinya.
Sejauh penelusuran penulis, kajian terhadap hadis menjaga lisan dan tangan sudah banyak dilakukan, namun kajiannya lebih megarah kepada dunia nyata, tanpa melihat dari segi media sosial. Sehinnga dalam hal ini, penulis mencoba menyuguhkan arah kajian baru dengan mengaplikasikan teori hermeneutic negosiatif Khaled Abou Fadl.

\section{PEMBAHASAN}

\section{Biografi Khaled Abou el-Fadl} Nama lengkapnya Khaled Medhat Abou el-Fadl, populer dengan nama Khaled Abou el-Fadl. Ayahnya bernama Medhat Abou elFadl dan ibunya Afaf el-Nimr. Lahir di Kuwait pada tahun 1963. Sebagaimana masyarakat Arab pada umumnya, Khaled sedari kecil telah dididik dengan ilmu-ilmu keislaman. Al-Qur'an, Hadits, Bahasa Arab, Tafsir, dan Tasawwuf telah diakrabinya sejak dari sekolah pendidikan dasar6. Ketika masih muda ia dikenal sebagai anak yang

6 Muhammad Sofyan, “Konsep Hermeneutika Otoritatif Khaled Abou ElFadl," KALAM 9, no. 2 (December 30, 2015): 3, https://doi.org/10.24042/klm.v9i2.337. 
cerdas. Pada usia 12 tahun, ia sudah hafal Al-Qur`an7 . Semasa kecil selain aktif mengikuti kelas Al-Qur'an dan Syari'ah di masjid lokal di daerahnya, al-Azhar, dia juga mempelajari semua koleksi buku orang tuanya yang berprofesi sebagai pengacara ${ }^{8}$ ).

Pada waktu mudanya Khaled adalah seorang aktivis gerakan Wahabi yang merupakan mazhab negara Kuwait. Namun ia kemudian memutuskan untuk menetap di Mesir setelah dia menyadari adanya kontradiksi dan persoalan akut di dalam konstruksi ideologis pemikiran kaum Wahabi. Khaled memperoleh gelar B.A. (Bachelor of Art) di Yale University, Amerika Serikat (1986). Setelah itu ia melanjutkan ke University of Pennsylvania dan selesai pada tahun 1989. Dan pada tahun 1999, dia melanjutkan ke Princeton University dengan spesialisasi dalam bidang

7 Yusriandi, "Hermeneutika Hadis Khaled M. Abou El-Fadl", dalam Kurdi dkk, Hermeneutika al-Qur'an dan Hadis (Yogyakarta: eLSAQ Press, 2010), 412-413.

8 Abid Rohmanu, Konsepsi Jihad Khaled M. Abou El Fadl dalam Perspektif Relasi Fikih, Akhlak dan Tauhid, Disertasi, (Surabaya: IAIN Sunan Ampel, 2010), 25.
Islamic Studies dan pada saat yang bersamaan ia menempuh studi hukum di Universitas California Los Angeles (UCLA) 9 .

Di UCLA pula, ia ditunjuk sebagai guru besar hukum Islam dengan mengampu sejumlah mata kuliah, seperti hukum Islam, imigrasi, HAM, dan hukum keamanan nasional dan internasional. Selain di UCLA, Khaled juga mengajar hukum Islam di universitas Texas dan Universitas Yale. Selain aktif mengajar di sejumlah universitas prestisius di dunia, ia juga mengabdikan dirinya dalam bidang advokasi dan pembelaan HAM, hakhak imigran, dan mengepalai sebuah lembaga HAM di Amerika. Pada tahun 2003- 2005, Khaled diangkat oleh George Walker Bush Presiden Amerika.

Di antara karya-karyanya yang sudah diterbitkan dalam bentuk buku adalah Speaking in God's Name:

9 Nasrullah, "Hermeneutika Otoritatif Khaled M. Abou El Fadl: Metode Kritik atas Penafsiran Otoritarianisme dalam Pemikiran Islam", dalam Jurnal Hunafa, Vol. 5, No. 2 (Desember, 2008), 140. 
Islamic Law, Authority and Woman;

Rebellion and Violence in Islamic Law; And God Knows the Soldiers: The Authoritative and Authoritarian in Islamic Discourse; The Authoritative and Authoritarian in Islamic Discourses: A Contemporary Case study; Islam and Challenge of Democracy; The Place of Tolerance in Islam; Conference of Books: The Search for Beauty in Islam. Karyakaryanya di atas pada umumnya sudah banyak diterjemahkan ke bahasa Indonesia. Di samping itu, masih banyak lagi tulisan ilmiah Abou El Fadl yang lain, baik dalam bentuk artikel maupun jurnal ilmiah ${ }^{10}$.

Di tengah-tengah kesibukannya sebagai profesor, Abou El Fadl sering diundang dan mengisi seminar, simposium, lokakarya, dan talk show di televisi dan radio seperti CNN, NBC, VOA, dan sebagainya. Belakangan ia banyak memberikan komentar tentang isu otoritas, terorisme, toleransi, dan hukum

10 Mutamakkin Billa, “Kritik-kritik Khaled M. Abou El Fadl atas Otoritarianisme dalam Diskursus Hukum Islam Kontemporer", Tesis (Yogyakarta: UIN Sunan Kalijaga Yogyakarta, 2005), 45.
Islam. Ia juga pernah menjabat direktur Human Right Watch dan anggota Komisi Kebebasan Beragama, Amerika Serikat.

Kegelisahan yang memunculkan tawaran dalam memahami agama adalah adanya lembaga fatwa yang dinilainya otoriter. Lembaga fatwa itu bernama Council for Scientific Research and Legal Opinions (CRLO) yang berlokasi di Saudi Arabia. Lembaga itu mengeluarkan sejumlah fatwa yang dianggap Abou El Fadl tidak rasional dan terlalu tendensius, terutama fatwa-fatwa terkait masalah perempuan. Lembaga ini juga sangat deskriminatif terhadap hak-hak publik perempuan, sehingga lembaga fatwa ini menjadi salah satu objek penelitiannya ${ }^{11}$.

\section{Hermeneutika Hadis Khaled}

\section{Abou el-Fadl}

Hermeneutika pada dasarnya adalah suatu metode atau cara untuk menafsirkan simbol yang berupa teks

11 Ahmad Suhendra, "Hermeneutika Hadis Khaled M. Abou El Fadl," Mutawatir 5, no. 2 (1 Desember 2015): 346, https://doi.org/10.15642/mutawatir.2015.5. 2.343-362. 
atau sesuatu yang diperlakukan sebagai teks untuk dicari arti dan maknanya. Disiplin hermeneutika lahir di Barat dari rahim agama Kristen sehingga sulit diterima dalam diskursus Islam ${ }^{12}$. Para intelektual muslim kontemporer menaruh kecurigaan pada gagasan Barat tentang relativisme dan antikemapanan, juga pada apa yang dipandang oleh sarjana muslim sebagai metodologi yang tidak menghormati nilai kesakralan ${ }^{13}$.

Terlepas dari persoalan tersebut, sejumlah cendikiawan muslim telah menggunakan metode hermeneutika dalam kajian Islam termasuk interpretasi makna AlQur'an, pangajuan otentisitas dan pemaknaan hadits, sehingga istilah "hermeneutika" tidak lagi merupakan istilah yang diberikan

12 Almirzanah, Syafa'atun dan Syamsuddin, Sahiron (eds.). Upaya Integrasi Hermeneutika dalam Kajian Qur'an dan Hadis: Teori dan Aplikasi, Tradisi Barat. (Yogyakarta: Lemlit UIN Sunan Kalijaga, 2009), 43

13 Hujair A. H. Sanaky, 'Gagasan Khaled Abou El Fadl Tentang Problem Otoritarianisme Tafsir Agama Pendekatan Hermeneutik Dalam Studi Fatwa-Fatwa Keagamaan', Al-Mawarid 14, no. 0 (15 January 2013). oleh pihak luar Islam (outsider) tetapi telah digunakan oleh orang Islam sendiri (insider) yang kemudian membawa konsekuensi pada perumusan metodologi ${ }^{14}$. Kemudian muncullah beberapa nama semisal Fazlur Rahman, Mohammad Arkoun, Nasr Hamid Abu Zayd, Hassan Hanafi, Abdullah Saeed, Aminah Wadud Muhsin, Khaled M. Abou ElFadl dan sebagainya ${ }^{15}$.

Pada awalnya hermeneutika yang ditawarkan oleh Abou Fadl digunakan untuk mengkritik hermeneutika otoriter komisi fatwa hukum Islam Timur Tengah. Menurutnya fatwa tersebut mengebiri otoritas Tuhan, membatasi peran Tuhan dan teks, mengunci rapat- rapat teks sehingga tidak ada ruang gerak yang dialogis antara teks, Tuhan dan pembaca. Padahal,

14 Abdul Majid, 'Hermeneutika Hadis Gender (Studi Pemikiran Khaled M. Abou El Fadl Dalam Buku Speaking in God's Name; Islamic Law, Authority And Women)', AlUlum 13, no. 2 (1 December 2013): 293-320.

15 Setiawan, M. Nur Kholis, dkk., Upaya Integrasi Hermeneutika dalam Kajian Qur'an dan Hadis: Teori dan Aplikasi, Tradisi Timur. Yogyakarta: Lembaga Penelitian UIN Sunan Kalijaga. 2011, 54. 
ketiga elemen tersebut yakni teks, Tuhan dan pembaca merupakan elemen pokok dalam pendekatan hermeneutika Khaleed Abou Fadl.

Sunnah dalam pandangan Abou El Fadl sebagai sebuah korpus riwayat tak berbentuk tentang perilaku, sejarah, dan perkataan (hadis) Nabi. Pandangan ini tentunya berbeda dengan apa yang telah didefinisikan para ulama pada umumnya. Menurut para ulama (hadis) sunnah mencakup lima aspek, yakni perkataan, perbuatan, persetujuan, sifat, dan perilaku hidupnya ${ }^{16}$.

Abou El Fadl melihat sunnah dalam dua bentuk, yakni bentuk lisan dan bentuk tulisan. Bentuk yang disebutkan pertama, merekam tradisi yang hidup dalam masyarakat Muslim terdahulu. Di dalam bentuk tulisan, hadis-hadis tersebut tidak lagi berubah dan berkembang tetapi terekam dalam bentuk yang

16 Yusuf al-Qaradhawi, Pengantar Studi Hadis, terj. Agus Suyadi Raharusun dan Dede Rodin (Bandung: Pustaka Setia, 1991), 20. terstruktur dan terorganisasi ${ }^{17}$. Dari uraian itu, bisa dikatakan bahwa Abou El Fadl membedakan antara terminologi sunnah dan hadis. Sunnah adalah kumpulan dari perilaku, kondisi sosio-politik dan perkataan Nabi, sedangkan hadis itu hanya terbatas pada perkataanperkataan Nabi.

Abou El Fadl mengakui bahwa konsep kepengarangan dalam hadis lebih kompleks dibanding dengan AlQur'an. Konsep kepengarangan dalam hadis melewati serangkaian perjalanan historis yang panjang. Oleh sebab itu, hadis merupakan hasil akhir dari perkembangan kumulatif yang terjadi melalui sebuah proses historis yang berlangsung secara terus-menerus. Implikasi dari itu adalah kandungan dari hadis mencerminkan suatu dinamika sosio-politik yang berlangsung selama berahun-tahun pasca wafatnya Nabi.

17 Khaled M. Abou El Fadl, Atas Nama Tuhan: Dari Fikih Otoriter ke Fikih Otoritatif, terj. R. Cecep Lukman (Jakarta: Serambi, 2004), 150. 
Hal mendasar yang ditawarkan Abou El-Fadl dalam kajian hadits adalah harus menyentuh realitas sejarah dengan mengembangkan kajian pada kritik matan yang memungkinkan seseorang mengkaji konteks sosiohistoris hadis untuk landasan kontekstualisasi pada masa kekinian. Selain itu, membaca fenomena dari riwayat hadis bukan berlandaskan atas apa yang telah dikatakan Nabi, tetapi peran apa yang dimainkan oleh Nabi dalam sebuah riwayat tersebut. Abou El Fadl lebih melihat dalam konteks apa yang menyebabkan Nabi mengucapkan suatu hadis tertentu, bukan pada muatan redaksionalnya ${ }^{18}$.

Dalam menyikapi hadis dengan segala komplekstisitas dalam proses penghimpunannya, maka perlu adanya interpretasi ulang terhadap hadis. Abou el-Fadl mengusulkan perlunya penetapan makna terhadap hadis. Penetapan makna disini pada dasarnya bukan

18 Ahmad Suhendra, 'Hermeneutika Hadis Khaled M. Abou El Fadl', Mutawatir 5, no. 2 (1 Desember 2015): 343-362. hanya persoalan penafsiran dan pemahaman, tetapi juga persoalan penentuan "penerapan" perintah dari teks otoritatif. Dengan kata lain, proses interpretasi bukan hanya upaya untuk memahami makna suatu kata atau ungkapan, tetapi juga cara menerapkan makna tersebut. Oleh karena itu Abou el-Fadl menyebut proses interpretasi dengan istilah yang lebih mendalam yaitu penetapan makna terhadap teks otorotatif, yang dalam hal ini adalah teks hadis ${ }^{19}$.

Abou el-Fadl menegaskan bahwa proses penetapan makna merupakan hasil interaksi antara pengarang (author), teks (text) dan pembaca (reader). Artinya, dalam penetapan makna harus ada proses negosiasi dari ketiga aspek tersebut secara seimbang tanpa ada dominasi dari salah satu pihak ${ }^{20}$.

19 Akrimi Matswah, "Hermeneutika Negosiatif Khaled M. Abou El Fadl Terhadap Hadis Nabi", ADDIN, Vol. 7, No. 2, (Agustus 2013), 257.

20 Khaled Abou el-Fadl, Speaking in God's Name: Islamic Law, Authority, and Woman, (Oxford: Oneworld Publications, 2003), 90. 
Hermeneutika negosiatif dapat diterapkan dengan beberapa langkah praktisnya, yaitu pertama terkait pemahaman tentang teks atau biasa disebut dengan perwakilan; bahwa teks memiliki kaidah bahasa sendiri, tidak memiliki kehendak pengarang, dan bersifat otonom serta terbuka. Langkah kedua adalah pengujian autentisitas (kompetensi) teks; yakni teks Al-Qur'an dan hadits sebagai sumber hukum bersifat terbuka, terutama teks hadits yang masih harus diuji autentisitasnya. Langkah ketiga ialah penetapan makna teks dengan melacak maksud awal pengarang teks, memahami komunitas makna di sekitar teks, memahami pesan moral dari universalitas teks, menganalisis asumsi-asumsi dalam komunitas interpretasi dan keseluruan bukti terkait teks, menemukan makna baru dari aplikasi teks pada masa kini, dan terakhir memisahkan subjektivitas penafsiran dari teks ${ }^{21}$.

21 Annas Muslihin, Signifikansi Hermeneutika dalam Kajian Hukum Islam Kontemporer: Studi atas Pemikiran Khaled Abou
Berdasarkan pembahasan di atas, penulis menyimpulkan bahwa hermeneutika hadis yang ditawarkan oleh Khaled Abu Fadl yang dikenal dengan istilah hermeneutikan negosiatif merupakan proses memahami suatu persolan yang di dalamnya melibatkan proses dialektika antara teks, pembaca dan realitas. Meskipun heremeneutika negosiatif ini lebih menekankan pada reader (pembaca), namun tidak mengesampingkan dua unsur lainnya, yakni teks dan realitas. Dikatakan pembaca lebih mengambil peran, karena pembacalah yang mengalami dinamika perubahan seiring dengan situasi dan kondisi yang menyelimutinya. Secara tidak langsung hal tersebut memberikan penegasan bahwa manusia memiliki keterbatasan, sehingga Khaled Abou el-Fadl menetapkan batasan-batasan untuk mencegah interpretasi yang sewenag-wenang.

El-Fadl, (DISERTASI, UIN Yogyakarta, 2013), $189-190$ 
3. Analisis Kandungan Hadis Menjaga Lisan Dan Tangan

Dan Implementasinya Di

\section{Media Sosial}

a. Kandungan Hadis Menjaga Lisan dan Tangan

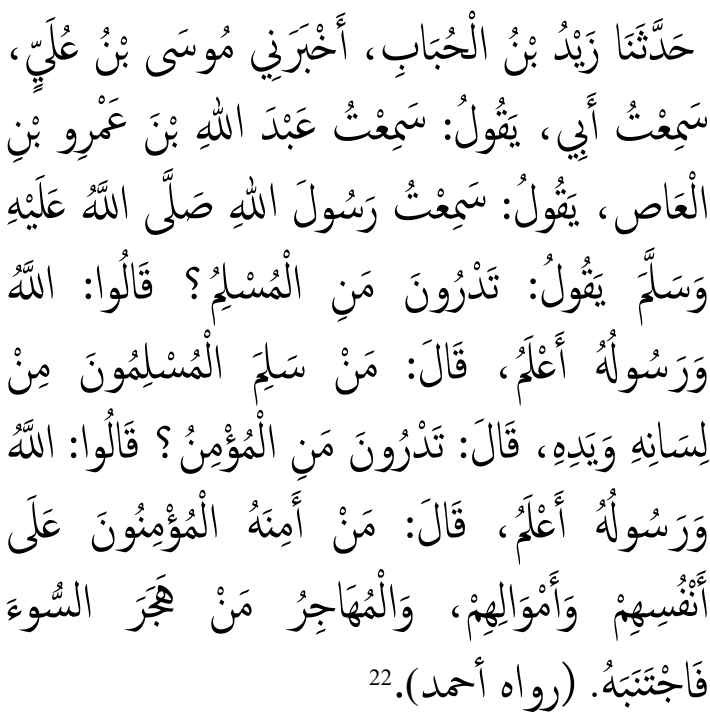

Artinya:

Telah menceritakan kepada kami Zaid Ibnul Hubbab telah mengkhabarkan kepadaku Musa bin Aliy aku mendengar bapakku berkata; Aku mendengar Abdullah bin 'Amru bin $\mathrm{Al}$ 'Ash berkata; aku mendengar Rasulullah Shallallahu 'alaihi wa Salam bersabda: "Tahukah kalian siapa itu muslim?" Mereka menjawab: "Allah dan Rasul-Nya lebih tahu." Beliau bersabda: "Seorang muslim adalah jika kaum muslimin merasa aman dari

22 Abu 'Abdullah Ahmad Ibn Hanbal, Musnad al-Imam Ahmad bin Hanbal, Jilid I,", 591. bahaya lisan dan tangannya." Beliau bersabda: "Tahukah kalian siapa itu mukmin?" Mereka menjawab: "Allah dan Rasul-Nya lebih tahu." Beliau bersabda: "Seorang mukmin adalah jika orang-orang mukmin merasa aman darinya terhadap jiwa dan harta mereka. Dan seorang Muhajir adalah orang yang menjauhi keburukan. (Ibnu Hanbal: 1421 $\mathrm{H})$.

b. Syarah Mufradat dan Syarah

\section{Kalimat}

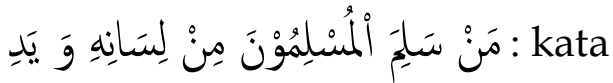

سَلِحِ terdiri dari tiga huruf dasar yaitu al-sin, al-lam dan al-mim. Sebagian besar mengartikan kata salima yaitu sehat dan kuat, di dalamnya tidak menyimpang atau tidak menyeleweng. Lebih jauh dijelaskan dalam Mu'jam Maqayis al-Lugah, kondisi seseorang dikatakan selamat ketika tidak adanya penyakit atau gangguan terhadap dirinya ${ }^{23}$. Dalam kamus Jamharah al-lugah kata salima merupakan lawan dari kata harb yakni kerusakan ${ }^{24}$.

23 Ahmad Warson Munawwir, AlMunawwir: Kamus Arab-Indonesia (Surabaya: Pustaka Progresif, 1997), 654.

${ }^{24}$ Abu Bakr Muhammad bin al-Hasan Ibn Duraidi al-Azdi, Jamharah al-Lugah, Juz II 
Lafal al-muslimuna merupakan ism fa'il yang menunjukkan jama' muzakkar al-salim karena adanya tambahan huruf al-waw dan al-nun pada lafal tersebut dan al-muslimuna merupakan fa'il dari salima.

Matan hadis tersebut menunjukkan salah satu karakter muslim. Sebagaimana salah satu makna Islam adalah "selamat" yang diambil dari asal kata salima, seorang muslim adalah seorang yang menyelamatkan. Hal itu merupakan kewajiban bagi setiap muslim dan haram hukumnya menyakiti muslim lainnya. Seseorang yang mengaku dirinya muslim maka ia harus selalu baik dalam perkataan dan perbuatannya. Sebagaimana firman Allah swt. dalam QS. alMu'minūn/23: 1-3.

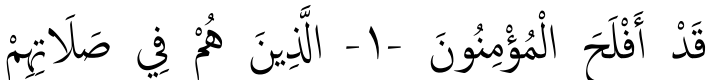

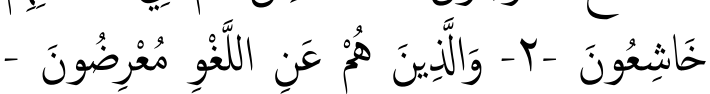

r- Terjemahnya:

(1) Sungguh beruntung orangorang yang beriman, (2) yaitu orang-orang yang khusyuk dalam salatnya, (3) dan orang yang menjauhkan diri dari

(Cet. I; Beirut: Dar al-'Ilm Lil Malayin, 1987), 858. (perbuatan dan perkataan) yang tidak berguna (Kementerian Agama RI: 2012).

Pada matan hadis tersebut Rasulullah saw., bertanya kepada sahabat dengan menggunakan lafal

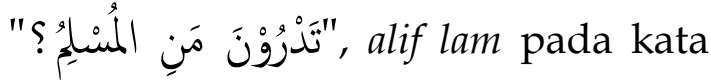
المسلم menunjukkan kesempurnaan seorang Mulim. Hal itu menunjukkan bahwa Rasulullah saw., memberitahukan kepada para sahabat bahwa Muslim yang sempurna ialah jika kaum muslimin merasa aman dari bahaya lisan dan tangannya. Namun, bukan berarti seorang muslim dikatakan sempurna ketika dia hanya memiliki sifat tersebut. Akan tetapi seorang muslim dikatakan sempurna keimanannya ketika ia memiliki sifat-sifat tersebut dan tetap menjaga cabang-cabang keimanan yang lainnya dan hadis tersebut tidak bermaksud mengingkari atau meniadakan keislaman seseorang apabila ia belum memiliki sifat tersebut ${ }^{25}$.

25 Abu Zakariyya Muhyi al-Din Ibn Syarf al-Nawawi, al-Azkar li al-Nawawi, Juz II (Cet. I; t.t.: Dar Ibn Hazm, 2004), 10. 
Al-Khatabi berkata: "Muslim yang paling utama adalah yang menunaikan hak-hak Allah dan hakhak manusia (Jalaluddin al-Suyuthi: 1986)." Selain itu dikatakan juga bahwa orang yang memiliki sifat tersebut merupakan orang yang berilmu. Seseorang yang berilmu akan bersifat sebagaimana ilmu yang ada padanya sama halnya dengan seorang muslim, jika ia adalah seorang muslim maka ia juga harus memiliki sifat selayaknya seorang muslim $^{26}$.

Ini juga menunjukkan bahwa hakikat Islam tidak hanya sekedar mengatur hubungan dengan Tuhan tetapi Islam juga mengatur hubungan sesama manusia yang semata-mata hanya mengharap ridho Allah.

Kata لسانه terdiri dari dua unsur, yaitu ism berupa al-lisan dan dhamir ha. Merupakan maf'ul bihi dari salima. Adapun al-lisan terambil dari kata kerja lasana, yang terdiri dari tiga huruf dasar yaitu al-lam, al-sin, dan

${ }^{26}$ Muhammad Anwar, Fathu al-Bari 'ala Shahih Bukhari, Juz I (Cet. I; Lebanon: Dar Kitab al-'Ilmiyyah, 2005), 153. al-nun. Ketiga huruf itu terangkai ke sebuah makna yang menunjukkan sesuatu yang (tidak terlalu) panjang, baik yang berhubungan dengan anggota tubuh maupun selainnya. Dhamir ha' pada lafal lisan merupakan mudafun ilaih karena dhamir tersebut bersambung dengan ism "lisanun". Makna dasar pada kata lisan yang diartikan sebagai organ tubuh dibagian mulut yang melahirkan kekuatan bicara (lidah). Karena yang terlahir darinya adalah ucapan yang dimengerti.

Bentuk pluralnya adalah alalsun. Jika dalam bentuk yang sangat banyak, disebut al-alsinah. Lafal allisan bersifat mużakkar dan bermakna perkataan yang tidak baik. Ibn Manz\}ur menambahkan bahwa terkadang bersifat mu'annas jika dikinayahkan dengan lafal al-kalimah. Sedangkan Ibn Sidah mengambil jalan tengah dengan berargumentasi bahwa lafal al-lisan bisa bersifat mużakkar dan juga bersifat mu'annas ${ }^{27}$ (Ibnu Manzur: 1414 H). Dari sini

27 Jamal al-Din Ibn Manzur al-Ifriqi, Lisan al-'Arab, Juz XIII Cet. III; (Beirut: Dar alSadir, 1993), 385. 
terambil lafal al-lasan yang bermakna perkataan yang baik dan fasih, al-lisn yang bermakna bahasa, dan jika dikatakan al-na'l al-mulassanah menunjukkan makna sebuah sendal yang berbentuk lisan (lidah). Begitu pula jika sesorang diberi sifat almalsūn, hal itu berarti ia seorang pendusta karena setiap ia ditanya, lisannya suka bergerak-gerak dan ia berkata hal-hal yang tidak sebenarnya ${ }^{28}$.

$$
\text { Penyebutan lafal لسان }
$$

didahulukan karena lisan menyakiti lewat perkataan sedangkan tangan menyakiti lewat perbuatan (Ibnu Hajar al-Asqalani: 1996). Jika pedang ataupun senjata api dapat menyebabkan kematian secara langsung, maka lidah lebih dari itu, ia bisa melukai dan susah untuk diobati. Jika luka yang diakbiatkan oleh senjata, seperti pisau, dapat diobati dan sembuh dalam hitungan hari, tidak bagi luka yang ditimbulkan oleh lidah yang jahat. Satu-satunya obat yang mungkin bisa

28 Abu al-Husain Ahmad Ibn Faris, Mu'jam Maqayis al-Lugah,, 247. menyembuhkannya

adalah

kematian $^{29}$.

Lidah juga paling mudah digunakan untuk menyakiti orang yang telah lalu, dengan menyebut aibnya dan kesalahannya dimasa lalu juga dapat menganggu orang yang ada sekarang dan orang yang akan datang dengan mencela dan mencacinya serta merendahkan diri saudaranya ${ }^{30}$.

Manusia diutamakan dari seluruh makhluk yang ada karena ia bisa mengucapkan keinginan akalnya yang diberikan Allah swt., lewat lidahnya ${ }^{31}$. Lidah merupakan penentu baik buruknya akhlak seseorang dan dapat menjadi sarana yang mengantarkan seorang muslim menuju kebahagiaan di akhirat. Lidah juga berperan menjungkalkan seorang muslim dalam kepahitan

29 Nasaruddin Umar, Menuai Fadhilah Dunia Menuai Berkah Akhirat (Jakarta: Kompas Gramedia, 2014), 121.

30 'Ali Saihun, al-Taswir al-Nabawi li alQaymi al-Khalqiyyati al-Tasyriyyati fi Hadis alSyarif, Juz I, Cet. I; (t.t: Maktabah al'Azhariyah al-Turast, 2002 ), 24.

31 Imad bin Hamdi al-Hakim, Kaifa Tasilin Ila Qalbi Zaujuki, terj. Fahrur Mu'is dan Ummu Najib Abdillah, Menjadi Isteri Penuh Pesona (Solo: Aqwam, 2007), 110. 
hidup di akhirat ${ }^{32}$. Karena, lidah bisa membuat anggota-anggota tubuh melakukan maksiat, tidak sukar digerakkan dan tidak sulit untuk mempergunakannya. ${ }^{33}$

Amal kedua mata hanya terbatas pada memandang dan amal kedua telinga fungsinya hanya terbatas pada mendengar. Sedangkan lidah, sekalipun kecil, mampu menjangkau segala sesuatu, baik yang haq maupun yang batil, menolak atau menerima, taat atau maksiat, iman atau kufur ${ }^{34}$. Segala perkataan yang keluar dari lisan merupakan cermin kepribadian seseorang. Lidah berkaitan erat dengan hati. Apa yang ada dalam hati akan terlontar melalui lidah. Hati yang tulus akan melahirkan

32 Lukman Santoso Az, Jagalah Lisanmu (Yogyakarta: Pustaka Insan Madani, 2008), 170.

33 Abdullah bin Jarullah, al-Bayan fi Afati al-Lisan, terj. Abu Haidar dan Abu Fahmi, Awas! Bahaya Lidah (Cet. I; Jakarta: Gema Insani Press, 1993), 7.

${ }^{34}$ Raja' Thaha Muhammad, Min Kunuz al-Sunnah Fil Akhlaq wa Suluki wa al-Usrati, terj. Fathurrahman Hamid, Hifzhul Lisan dan Penuntun Akhlak Keluarga (Cet. I; Semarang: Pustaka Adnan, 2005), 1. perkataan yang menentramkan pendengarnya.

Menjaga lidah untuk selalu berkata baik bukan hal yang mudah. Tetapi, harus tetap dilakukan karena dalam kehidupaan sehari-hari, manusia tidak akan pernah lepas dari komunikasi dengan orang lain dan komunikasi tersebut dilakukan dengan lidah. Untuk menjadi orang bijaksana, manusia dituntut untuk tahu bagaimana menggunakan lidahnya, kapan dan bagaimana, sehingga ia berkata pada tempatnya dan diam pada tempatnya ${ }^{35}$. Dalam situasi tertentu ada beberapa ucapan yang jika dilihat dari segi zohirnya, itu adalah ucapan yang tidak baik. Akan tetapi, Islam memandang hal itu perlu dilakukan karena mengandung manfaat yang lebih besar.

\section{A. Analisis Aplikasi}

Hermeneutika Khaled Abou elFadl

${ }^{35}$ Khalil al-Musawi, Kaifa Tatasharruf bi Himah, terj. Ahmad Subandi, Bagaimana Menjadi Orang yang Bijaksana: Resep-Resep Mudah dan Sederhana meraih Hikmah dalam Kehidupan, (Cet. I; Jakarta: Lentera, 1998), 154. 
Pada akhir pembahasan ini, penulis mencoba menerapakan teori heremeneutika negosiatif Khaled Abou Fadl dalam menyikapi persoalan menjaga lisan dan tangan implementasinya terhadap dunia medsos. Sebagaiaman telah kami paparkan sebelumnya bahwa intisari pendekatan hermeneutika yang ditawarkan oleh Abou El-Fadl tidak hanya bertujuan untuk "menemukan makna teks" seperti kajian hermeneutika pada umumnya, melainkan juga bertujuan untuk mengungkapkan kepentingan penggagas atau pembaca yang berada di balik teks serta menawarkan strategi pengendalian tindakan kesewenangan pembaca terhadap teks sehingga tidak terjerumus dalam ruang otoriter dan otoritarianisme ${ }^{36}$.

${ }^{36}$ Labib Muttaqin, "Positifisasi Hukum Islam dan Formalisasi Syari'ah Ditinjau dari Teori Otoritarianisme Khaled Abou El-Fadl,"
Adapun langkah awal yang ditawarkan oleh Abu el-Fadl, yaitu pemahaman teks yang bersifat terbuka, dalam hal ini tentu adalah pemahaman hadis di atas yang telah dipaparkan penulis pada sub-bab syarh hadis. Langkah kedua adalah melihat autentisitas teks dengan hasil bahwa hadis tentang menjaga lisan dan tangan adalah adalah hadis sahịị dan langkah terakhir adalah penetapan makna, di sinilah terjadinya proses negosisasi yang dimaksud oleh Abou ElFadl ${ }^{37}$.

Makna yang ingin disampaikan Rasululllah saw sebagai author adalah menjaga lisan dan tangan menunjukkan salah satu karakter muslim. Sebagaimana salah satu makna Islam adalah "selamat" yang

Al Ihkam: Jurnal Hukum \& Pranata Sosial 11, no. 1 (July 1, 2016): 5.

37 Choirul Mahfud, "Understanding Education of Authoritative Islamic Law Perspective Khaled Abou El Fadl," MODELING: Jurnal Program Studi PGMI 6, no. 1 (March 13, 2019): 8. 
diambil dari asal kata salima, seorang muslim adalah seorang yang menyelamatkan. Hal itu merupakan kewajiban bagi setiap muslim dan haram hukumnya menyakiti muslim lainnya. Seseorang yang mengaku dirinya muslim maka ia harus selalu baik dalam perkataan dan perbuatannya. Hal ini senada dengan apa yang dikatakan Al-Nawawi bahwa: "Perkataan adalah sarana untuk menyampaikan maksud. Setiap maksud baik yang bisa dicapai dengan tanpa menggunakan kebohongan, maka dalam situasi ini diharamkan bohong. Namun jika memang tidak bisa tercapai kecuali dengan kebohongan maka dalam situasi ini dibolehkan berbohong. Kemudian, jika maksud yang akan dicapai itu mubah maka bohong itu juga mubah dan jika wajib maka bohong itu juga wajib.

Demikianlah, Islam menganjurkan berkata baik dan jujur. Namun demikian terdapat kebolehan berbohong apabila memenuhi beberapa unsur: pertama, seseorang yang ingin mendamaikan dua orang yang berseteru; kedua, berbohong terhadap musuh untuk menjaga rahasia pasukan atau negara Islam. Jadi, inilah proses negosiasi terhadap teks yang dimaksudkan oleh Abou Fadll, hukum asal berkata jujur itu diharuskan akan tetapi dibolehkan di beberapa kondisi tertentu asalkan memenuhi kriteria kebolehan dalam Islam. Hemat penulis, meskipun ada unsur pembolehan, namun melihat dunia medsos yang sesak dengan isu sara dan penyebaran hoax, belum lagi tren media sosial yang mana menjadi lahan pencarian uang seperti youtube, wa dan media sosial lainnya secara bebas mengumbar kebencian tanpa memperhatikan aspek hukum menjaga lisan. Maka, perlu kiranya persolan menjaga lisan ini tidak hanya didudukkan dalam konteks hukum dan normative. Melainkan 
melibatkan budaya dan normanorma kehidupan. Dalam konteks masyarakat timur yang mengacu pada nilai-nilai dan tatanan ketimuran menggangap bahwa manusia adalah bagian dari manusia yang lain yang tidak terpisahkan sehingga membentuk sebuah masyarakat yang sejahtera terhindara dari pembodohan akibat tidak menjaga lisan.

\section{SIMPULAN}

Kandungan hadis tentang menjaga lisan dan tangan ialah menunjukkan salah satu karakter muslim. Sebagaimana salah satu makna Islam adalah "selamat" yang diambil dari asal kata salima, seorang muslim adalah seorang yang menyelamatkan. Hal itu merupakan kewajiban bagi setiap muslim dan haram hukumnya menyakiti muslim lainnya. Seseorang yang mengaku dirinya muslim maka ia harus selalu baik dalam perkataan dan perbuatannya.

Hadis Rasulullah Saw., yang menganjurkan umatnya agar senantiasa menjaga lisan dan tangannya, belum mendapat perhatian yang serius dari kalangan umat Islam. Karena masih banyak di antara mereka yang mengaku Islam akan tetapi perilaku dan perbuatannya tidak mencerminkan sebagaimana perilaku yang dimilki oleh orang Islam. Mereka menggunakan lisannya untuk mengatakan hal-hal yang keji serta menggunakan tangannya pada halhal yang dapat merusak dirinya maupun orang disekitarnya.

Sebagai simpulan dari aplikasi teori hermeneutika negosiatif Khaled Abou Fadl, maka penulis menarik benang merah, bahwa menjaga lisan dimedia sosial sangat membantu terbentuknya tatanan msyarakat yang ideal dan berkerahmatan meski ada pembolehan tidak berkata jujur, akan tetapi aspek kekinian yang terjadi dimedia sosial lebih banyak mudharatnya. 


\section{DAFTAR PUSTAKA}

Ahmad Ibn 'Ali bin Hajar Abu alFadl al-'Asqalani al-Syafi'i, Fath al-Bari Syarh Sahih Bukhari terj. Abu Ihsan al-Atsari, Fathul Bari Syarah Shahih al-Bukhari, Juz I, Cet. II; t.t: Pustaka Imam Syafi'i, 2010

Al-Azdi, Abu Bakr Muhammad bin al-Hasan Ibn Duraidi, Jamharah al-Lugah, Juz II. Cet. I; Beirut: Dar al-`Ilm Lil Malayin, 1987

Al-Hakim, Imad bin Hamdi, Kaifa Tasilin Ila Qalbi Zaujuki, terj. Fahrur Mu' is dan Ummu Najib Abdillah, Menjadi Isteri Penuh Pesona, Solo: Aqwam, 2007

Al-Ifriqi, Jamal al-Din Ibn Manzur, Lisan al-'Arab, Juz XIII, Cet. III; Beirut: Dār al-Sāadir, 1993

Al-Jawazi, Jamal al-Din Abu al-Faraji 'Abd al-Rahman Ibn 'Ali Ibn Muhammad, Kasfy al-Musykil min Hadis al-Sahihain, Jilid III, Riyadh: Dar al-Watan, t.th

Al-Ju'fi, Muhammad Ibn Isma'il Abu Abdillah al-Bukhari, al-Jami' alSahih, Jilid VIII, Beirut: Dar Ibn Kasir, 1987

Almirzanah, Syafa'atun dan Syamsuddin, Sahiron (eds.). Upaya Integrasi Hermeneutika dalam Kajian Qur'an dan Hadis: Teori dan Aplikasi, Tradisi Barat. Yogyakarta: Lemlit UIN Sunan Kalijaga, 2009

Al-Musawi, Khalil, Kaifa Tatasharruf bi Himah, terj. Ahmad Subandi, Bagaimana Menjadi Orang yang Bijaksana: Resep-Resep Mudah dan Sederhana meraih Hikmah dalam Kehidupan, Cet. I; Jakarta: Lentera, 1998

Al-Naisaburi, Muslim Ibn al-Hajjaj Abu al-Husain al-Qusyairi,
Sahih Muslim, jilid 1, Beirut: Dar Ihya' al-Tarat al-'Arabi, t. Th

Al-Nawawi, Abu Zakariyya Muhyi al-Din Yahya Ibn Syarf, alManhaj Syarh Sahih Muslim Ibn al-Hajjaj, Juz II. Cet. II; Beirut: Dar Ihya' al-Turas, 1972

Abu Zakariyya Muhyi al-Din Ibn Syarf, al-Azkar li alNawawi, Juz II, Cet. I; t.t.: Dar Ibn Hazm, 2004

Al-Qaradhawi, Yusuf, Pengantar Studi Hadis, terj. Agus Suyadi Raharusun dan Dede Rodin, Bandung: Pustaka Setia, 1991

Al-Suyuti, 'Abd al-Rahman Ibn Abi Bakr Jalal al-Din, Hasyiah alSanadi 'ala Sunan al-Nasa'i, Juz VIII, Cet. II; Halb: Maktabah alMatbuah al-Islamiah, 1986

Al-Syaibani, Abu 'Abdullah Ahmad Ibn Muhammad Ibn Hanbal Ibn Hilal Ibn Asdi, Musnad al-Imam Ahmad bin Hanbal, Jilid I, Cet. I; t.t.: $\mathrm{Mu}^{\prime}$ assasah al-Risalah, 2000

Anwar, Muhammad, Fathu al-Bari 'ala Sahih Bukhari, Juz I, Cet. I; Lebanon: Dar Kitab al'Ilmiyyah, 2005

Billa, Mutamakkin, "Kritik-kritik Khaled M. Abou El Fadl atas Otoritarianisme dalam Diskursus Hukum Islam Kontemporer", Tesis, Yogyakarta: UIN Sunan Kalijaga Yogyakarta, 2005

El-Fadl, Khaled Abou, Speaking in God's Name: Islamic Law, Authority, and Woman, Oxford: Oneworld Publications, 2003.

Khaled M. Abou, Atas Nama Tuhan: Dari Fikih Otoriter ke Fikih Otoritatif, terj. R. Cecep Lukman, Jakarta: Serambi, 2004

Faris, Abū al-Husain Ahmad Ibn, Mu'jam Maqayis al-Lugah, Jilid 
VI, Beirut: Dar al-Fikr alIlmiyya, 2011

Hamid, Raja' Thaha Muhammad Ahmad, Min Kunuz al-Sunnah, Terj. Fathurrahman, Akhlaqi wa al-Suluki wa al-Suluti Hifzhul Lisan dan Penuntun Akhlak Keluarga, Cet. I; Semarang: Pustaka Adnan, 2005

Jarullah, Abdullah bin, al-Bayan Fi Afati al-Lisan, terj. Abu Haidar dan Abu Fahmi, Awas! Bahaya Lidah, Cet. I; Jakarta: Gema Insani Press, 1993

Majid, 'Abdul, Hermeneutika Hadis Gender (Studi Pemikiran Khaled M. Abou El Fadl Dalam Buku Speaking in God's Name; Islamic Law, Authority and Women), Al-Ulum 13, no. 2, 1 December 2013

Matswah, Akrimi, "Hermeneutika Negosiatif Khaled M. Abou El Fadl Terhadap Hadis Nabi", ADDIN, Vol. 7, No. 2, Agustus 2013

Muhammad, Raja' Thaha, Min Kunuz al-Sunnah Fil Akhlaq wa Suluki wa al-Usrati, terj. Fathurrahman Hamid, Hifzhul Lisan dan Penuntun Akhlak Keluarga, Cet. I; Semarang: Pustaka Adnan, 2005

Munawwir, Ahmad Warson, AlMunawwir: Kamus ArabIndonesia, Surabaya: Pustaka Progresif, 1997

Muslihin, Annas, Signifikansi Hermeneutika Dalam Kajian Hukum Islam Kontemporer: studi atas pemikiran Khaled Abou ElFadl, DISERTASI, UIN Yogyakarta, 2013

Nasrullah, "Hermeneutika Otoritatif Khaled M. Abou El Fadl: Metode Kritik atas Penafsiran Otoritarianisme dalam Pemikiran Islam", dalam Jurnal Hunafa, Vol. 5, No. 2, Desember, 2008
Rohmanu, Abid, Konsepsi Jihad Khaled M. Abou El Fadl dalam Perspektif Relasi Fikih, Akhlak dan Tauhid, Disertasi, Surabaya: IAIN Sunan Ampel, 2010

Saihun, 'Ali, al-Taswir al-Nabawi li alQaymi al-Khalqiyyati alTasyriyyati fi Hadis al-Syarif, Juz I, Cet. I; t.t: Maktabah al'Azhariyah al-Turas, $2002 \mathrm{M}$

Santoso Az Lukman, Jagalah Lisanmu, Yogyakarta: Pustaka Insan Madani, 2008

Setiawan, M. Nur Kholis, dkk., Upaya Integrasi Hermeneutika dalam Kajian Qur'an dan Hadis: Teori dan Aplikasi, Tradisi Timur. Yogyakarta: Lembaga Penelitian UIN Sunan Kalijaga, 2011

Suhendra, Ahmad, 'Hermeneutika Hadis Khaled M. Abou El Fadl', Mutawatir 5, no. 2, 1 December 2015

Ahmad, "Hermeneutika Hadis Khaled M. Abou El Fadl," Mutawatir 5, no. 2, 1 Desember 2015):

346 ,

https://doi.org/10.15642/mutawatir.2 $\underline{015.5 .2 .343-362}$

Umar, Nasaruddin, Menuai Fadhilah Dunia Menuai Berkah Akhirat, Jakarta: Kompas Gramedia, 2014

Yusriandi, "Hermeneutika Hadis Khaled M. Abou El-Fadl", dalam Kurdi dkk, Hermeneutika Al-Qur'an dan Hadis, Yogyakarta: eLSAQ Press, 2010

Muttaqin, Labib, "Positifisasi Hukum Islam dan Formalisasi Syari'ah Ditinjau dari Teori Otoritarianisme Khaled Abou El-Fadl," Al Ihkam: Jurnal Hukum \& Pranata Sosial 11, no. 1, July 1, 2016

Sofyan, Muhammad, "Konsep Hermeneutika Otoritatif Khaled Abou El-Fadl," KALAM 9, no. 2, 
December 30, 2015:,

https://doi.org/10.24042/klm.v9i2.33

$\underline{7}$

Mahfud, Choirul, "Understanding

Education of Authoritative

Islamic Law Perspective Khaled

Abou El Fadl," MODELING:

Jurnal Program Studi PGMI 6, no.

1, March 13, 2019 